\title{
Takotsubo Cardiomyopathy during Acute Adrenal Crisis due to Isolated Adrenocorticotropin Deficiency
}

\author{
Chizuko Ukita ${ }^{1}$, Hiroshi Miyazaki ${ }^{2}$, Nagaoki Toyoda ${ }^{1}$, Atsushi Kosaki ${ }^{1}$, \\ Mitsushige Nishikawa ${ }^{1}$ and Toshiji Iwasaka ${ }^{1}$
}

\begin{abstract}
We report a 69-year-old woman who had isolated adrenocorticotropic hormone (ACTH) deficiency. Subsequently, she had Takotsubo cardiomyopathy during acute adrenal crisis. Replacement therapy with hydrocortisone sufficiently improved her cardiomyopathy. We conclude that her myocardial dysfunction was closely related to adrenal insufficiency and suggest that in certain circumstances, adrenal crisis may cause Takotsubo cardiomyopathy.
\end{abstract}

Key words: Takotsubo cardiomyopathy, adrenal crisis, isolated adrenocorticotropin deficiency

(Inter Med 48: 347-352, 2009)

(DOI: 10.2169/internalmedicine.48.1662)

\section{Introduction}

Takotsubo cardiomyopathy is characterized by transient left ventricular apical wall motion abnormality with electrocardiographic changes and minimal myocardial enzymatic release mimicking acute myocardial infarction, but without significant coronary artery disease (1-6). The causes of Takotsubo cardiomyopathy remain unclarified $(7,8)$.

Adrenal crisis is rapid and overwhelming intensification of chronic adrenal insufficiency. In the presence of severe stress, such as infection, trauma (including surgery), gastrointestinal upsets, or other stress, which requires an immediate increase in glucocorticoid, the blood pressure and the pulse fail as hypovolemic vascular shock ensues $(9,10)$. This state is usually termed adrenal crisis. However, cardiomyopathy induced by adrenal crisis is very uncommon (1118).

Here, we report a case of Takotsubo cardiomyopathy during acute adrenal crisis due to isolated adrenocorticotropic hormone (ACTH) deficiency. The possible relation of this disease combination will be discussed.

\section{Case Report}

A 69-year-old woman patient was admitted to Kyoto First
Red Cross Hospital in December 2002, complaining of general fatigue and loss of appetite for about six months. She had been in good health until that time. She lost $3 \mathrm{~kg}$ in 6 months. Family and past histories were noncontributory. When she delivered two healthy babies, there were no complications including massive bleeding or shock.

On admission, she was thin, $151 \mathrm{~cm}$ tall and weighed 40 $\mathrm{kg}$. Her body temperature was $36.0^{\circ} \mathrm{C}$, blood pressure; 106/ $60 \mathrm{mmHg}$, and pulse rate; 90/min. Physical examination showed no abnormalities except that she was apathic. Her skin and mucosa was free of unusual pigmentation. Laboratory findings revealed normochromic and normocytic anemia. Low serum levels of sodium $(125 \mathrm{mEq} / \mathrm{L})$, chloride, albumin and cholinesterase were evident (Table 1). On electrocardiogram (ECG), $\mathrm{T}$ waves were inverted in leads V1 and 2, and diphasic in leads V3, and 4, but these were minor abnormalities (Fig. 1). Since basal serum concentrarion of cortisol was undetectable $(<0.1 \mu \mathrm{g} / \mathrm{dL})$, further studies were designed for adrenocortical insufficiency.

However, on the following day, she was found to have impaired consciousness, and was pale and sweating. Her blood pressure was $80 / 58 \mathrm{mmHg}$, body temperature $40.2^{\circ} \mathrm{C}$. The blood glucose was $0.88 \mathrm{mmol} / \mathrm{L}$, and the diagnosis of acute adrenal crisis was made. She responded to intravenous glucose, sodium chloride and hydrocortisone. Initially, intravenous administration of $100 \mathrm{mg}$ of hydrocortisone four

${ }^{1}$ The Second Department of Internal Medicine, Kansai Medical University, Osaka and ${ }^{2}$ Miyazaki Clinic, Kyoto Received for publication September 4, 2008; Accepted for publication November 3, 2008 Correspondence to Dr. Chizuko Ukita, ukitac@ hirakata.kmu.ac.jp 
Table 1. Laboratory Findings on Admission

\begin{tabular}{lr} 
Peripheral blood & \\
White blood cells & $6,440 / \mu \mathrm{L}(3,000-8,600)$ \\
$\quad$ Neutrophils & $53.2 \%(40-76)$ \\
Lymphocytes & $34.9 \%(17-49)$ \\
$\quad$ Monocytes & $5.9 \%(2-11)$ \\
$\quad$ Basophils & $0.5 \%(0-2.5)$ \\
$\quad$ Eosinophils & $3.2 \%(0-8)$ \\
Red blood cells & $346 \times 10^{4} / \mu \mathrm{L}(370-520)$ \\
Hemoglobin & $10.7 \mathrm{~g} / \mathrm{dL}(11.0-15.8)$ \\
Hematocrit & $31.6 \%(33-48)$ \\
Platelet & $22.1 \times 10^{4} / \mu \mathrm{L}(15-40)$ \\
Serum chemistry & $125 \mathrm{mEq} / \mathrm{L}(137-147)$ \\
Sodium & $4.5 \mathrm{mEq} / \mathrm{L}(3.5-4.8)$ \\
Potassium & $91 \mathrm{mEq} / \mathrm{L}(95-110)$ \\
Chloride & $75 \mathrm{mg} / \mathrm{dL}(70-110)$ \\
Glucose & $11 \mathrm{mg} / \mathrm{dL}(8-20)$ \\
Urea nitrogen & $0.43 \mathrm{mg} / \mathrm{dL}(0.4-1.1)$ \\
Creatinine & $2.9 \mathrm{mg} / \mathrm{dL}(2.5-6.0)$ \\
Uric acid & $140 \mathrm{IU} / \mathrm{L}(43-165)$ \\
Creatine kinase & $6.4 \mathrm{~g} / \mathrm{dL}(6.0-8.0)$ \\
Total protein & $3.7 \mathrm{~g} / \mathrm{dL}(3.8-5.3)$ \\
Albumin & $37 \mathrm{IU} / \mathrm{L}(7-40)$ \\
AST $* 1$ & $20 \mathrm{IU} / \mathrm{L}(7-40)$ \\
ALT $* 2$ & $192 \mathrm{IU} / \mathrm{L}(106-211)$ \\
Lactate dehydrogenase & $122 \mathrm{IU} / \mathrm{L}(190-420)$ \\
Choline-esterase & $0.4 \mathrm{mg} / \mathrm{dL}(0.1-1.0)$ \\
Total bilirubin & $168 \mathrm{mg} / \mathrm{dL}(150-220)$ \\
Total cholesterol & $76 \mathrm{mg} / \mathrm{dL}(50-150)$ \\
Criglyceride & $0.6 \mathrm{mg} / \mathrm{dL}(<0.3)$ \\
& \\
\hline &
\end{tabular}

Figures in parentheses indicate the normal ranges. *1: aspartate aminotransferase, $* 2$ : alanine

aminotransferase.

times daily was started, and then $100 \mathrm{mg}$ of hydrocortisone three times daily was given intravenously. Urine culture specimen obtained before antibiotic therapy demonstrated $E$. coli proliferation. On the third hospital day, she developed a sudden chest pain. From the ECG monitoring, ventricular tachycardia (VT) was detected. After intravenous administration of $50 \mathrm{mg}$ of lidocaine, cardioversion with 200J was effective to terminate VT. Deep negative T waves in leads I, II, III, aVf and V1-6 were revealed on ECG (Fig. 1). Serum levels of creatinine kinase (CK)(6,732 IU/L), CK-MB (162 IU/L) and GOT (154 IU/L) elevated. Plasma levels of noradrenaline $(1,038 \mathrm{pg} / \mathrm{mL})$ and dopamine $(507 \mathrm{pg} / \mathrm{mL})$ also elevated. Echocardiography showed left ventricular systolic dysfunction [ejection fraction (EF) 33\%]. On emergent cardiac catheterization, coronary arteriography showed no significant stenosis and the ergonovine provocation test was negative. Left ventriculography revealed akinesis in anterolateral, apical and diaphragmatic segments (Fig. 2). These findings were consistent with Takotsubo cardiomyopathy.

On the fifth hospital day, her chest pain disappeared. Steroid administration was changed to hydrocortisone $20 \mathrm{mg} /$ day per os, and her clinical condition such as general fatigue and loss of appetite markedly improved in a few days. On the eighth hospital day, left ventricular wall motion abnormalities recovered except for apical segment, and systolic function improved (EF 74\%) on the echocardiogram. Blood tests revealed CK of 168 IU/L, GOT of 29 IU/L. Three weeks later, left ventricular wall motion returned to normal. ECG showed improving T-wave inversion during the course, but was still apparent in leads V3-6 (Fig. 1). Abdominal computed tomography revealed no evidence of pheochromocytoma. 


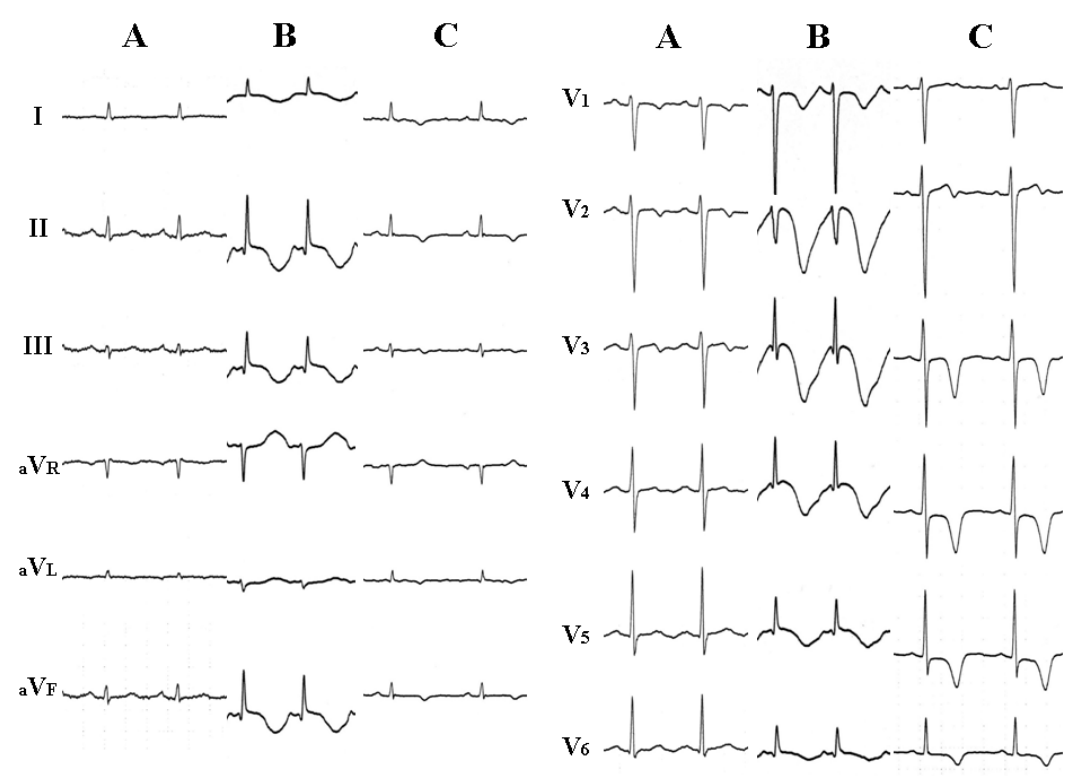

Figure 1. Time course of electrocardiogram. On admission (A), T wave changes were slight. At 2 days later (B), negative T waves were seen in leads I, II, III, aVf and V1-6. At 3 weeks later (C), improved $T$ wave inversion was shown, but it was still slightly seen in leads V3-6.
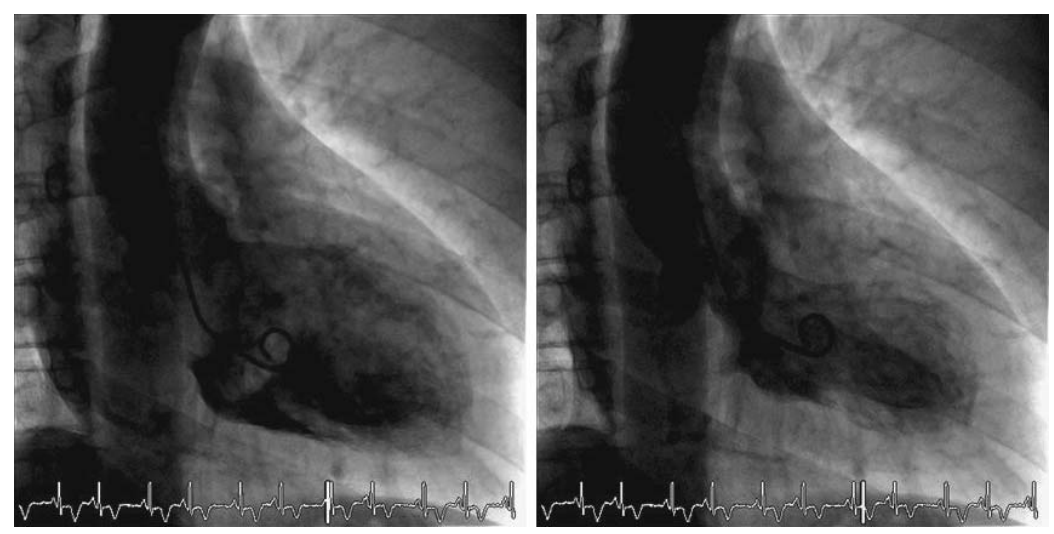

Figure 2. Left ventriculography showed apical akinesis and basal hyperkinesis in the acute phase.

Endocrine studies showed decreased serum cortisol $(<1.0$ $\mu \mathrm{g} / \mathrm{dL}$ ) and a decreased urinary excretion of 17-hydroxy corticosteroids (17OHCS) (2.3 mg/day) with a decreased serum ACTH level $(<5.0 \quad \mathrm{pg} / \mathrm{mL})$. Plasma cortisol responded slightly after a bolus injection of $0.25 \mathrm{mg} \mathrm{ACTH}$, however, ACTH-Z (0.5 mg daily injection for 3 days) increased urinary $17 \mathrm{OHCS}$ excretion to $10 \mathrm{mg} /$ day. ACTH-releasing hormone did not increase the plasma ACTH concentration $(<5.0$ $\mathrm{pg} / \mathrm{mL}$ ). Thyroid stimulating hormone (TSH) (basal value: 8.17- peak value: $36.0 \mu \mathrm{U} / \mathrm{mL})$, prolactin $(58-89 \mathrm{ng} / \mathrm{mL})$, luteinizing hormone $(\mathrm{LH})(0.9-12 \mathrm{mIU} / \mathrm{mL})$, follicle stimulating hormone $(19-43 \mathrm{mIU} / \mathrm{mL})$ and growth hormone $(\mathrm{GH})$ (3.31-30.6 ng/mL) were all increased by infusing TSHreleasing hormone, LH-releasing hormone and GH-releasing hormone. Plasma renin activity $(0.8 \mathrm{ng} / \mathrm{mL} / \mathrm{h})$ and plasma aldosterone concentration $(25 \mathrm{pg} / \mathrm{mL})$ were normal. Therefore, the diagnosis of isolated ACTH deficiency was made. Magnetic resonance imaging (MRI) revealed no pituitary lesions nor adjacent lesions.

\section{Discussion}

Adrenal insufficiency may be secondary due to a primary failure in the elabolation of ACTH. The clinical signs of isolated ACTH deficiency are characterized by deficiencies of glucocorticoids and adrenal androgen, which is under the control of ACTH $(9,10,19)$. The present case complained of fatigability and anorexia for 6 months, which agree with the clinical findings of deficiency of glucocorticoid. The cause of isolated ACTH deficiency is unclear, but it was considered that she had suffered from secondary insufficiency for at least 6 months (i.e., chronic adrenocortical insufficiency) and that pyelonephritis induced adrenal crisis.

Several reports from Japan have described patients with transient left ventricular apical ballooning without significant coronary artery disease. This asynergy is called Takotsubo cardiomyopathy (1-6), and the syndrome is now established worldwide $(7,8,20,21)$. However, universally accepted di- 
Table 2. Reported Cases with Isolated ACTH Deficiency Complicated with Reversible Cardiomyopathy

\begin{tabular}{|c|c|c|c|c|c|c|c|c|c|c|}
\hline Case & $\begin{array}{l}\text { Age/ } \\
\text { Sex }\end{array}$ & $\begin{array}{l}\text { Underlying } \\
\text { disorder }\end{array}$ & Trigger event & Symptoms & $\begin{array}{l}\text { Coronary } \\
\text { angiogram }\end{array}$ & $\begin{array}{l}\text { Normalization } \\
\text { of left } \\
\text { ventricular } \\
\text { contraction }\end{array}$ & $\begin{array}{l}\text { Normalization } \\
\text { of deep negative } \\
\text { T waves }\end{array}$ & $\begin{array}{l}\text { Biopsy } \\
\text { pathology }\end{array}$ & $\begin{array}{l}\text { Duration of } \\
\text { hydrocortisone } \\
\text { therapy }\end{array}$ & Reference \\
\hline 1 & $74 / \mathrm{F}$ & $\begin{array}{l}\text { Degenerative } \\
\text { joint disease }\end{array}$ & $\begin{array}{l}\text { Knee joint } \\
\text { surgery }\end{array}$ & - & $\begin{array}{l}\text { No } \\
\text { abnormalities }\end{array}$ & 5 days & 4 weeks & - & Details unclear & 16 \\
\hline 2 & $64 / \mathrm{F}$ & - & infection & unconsiousness & normal & 2 weeks & 5 weeks & - & Details unclear & 16 \\
\hline 3 & $62 / \mathrm{F}$ & - & - & fatigue & $\begin{array}{l}\text { No significant } \\
\text { stenosis }\end{array}$ & 2 months & 2 weeks & - & $20 \mathrm{mg} / \mathrm{d}$ PO & 17 \\
\hline 4 & $53 / \mathrm{F}$ & $\begin{array}{l}\text { Chronic } \\
\text { thyroiditis }\end{array}$ & - & unconsiousness & $\begin{array}{l}\text { No significant } \\
\text { stenosis }\end{array}$ & 2 weeks & - & $\begin{array}{l}\text { Focal } \\
\text { myocyte } \\
\text { injury }\end{array}$ & $\begin{array}{l}200 \mathrm{mg} / \mathrm{d} \text { IV for } \\
1 \text { week } \\
15 \mathrm{mg} / \mathrm{d} \text { PO for } \\
\text { a further week }\end{array}$ & 18 \\
\hline 5 & $69 / \mathrm{F}$ & - & pyelonephritis & Chest pain & $\begin{array}{l}\text { No significant } \\
\text { stenosis }\end{array}$ & 5 days & 3 weeks & - & $\begin{array}{l}400 \mathrm{mg} / \mathrm{d} \text { IV for } \\
2 \text { days } \\
300 \mathrm{mg} / \mathrm{d} \text { IV for } \\
1 \text { day } \\
20 \mathrm{mg} / \mathrm{d} \text { PO }\end{array}$ & $\begin{array}{l}\text { Present } \\
\text { case }\end{array}$ \\
\hline
\end{tabular}

PO: per os, IV: intravenously, d: day.

agnostic criteria for this syndrome are not yet available. Major clinical characteristics are that 1) the symptoms are similar to those of acute myocardial infarction; 2) most patients are elderly women; 3) takotsubo-like left ventricular dysfunction, which extends over more than one coronary artery region, is transient and dramatically resolves within several weeks. These findings are consistent with those of this patient. Myocardial damage is usually excluded when the CKMB is $<5$ or $6 \%$ of the total CK activity (22). In the present case, the CK-MB was $2.4 \%$ of the total CK activity. The extent of CK elevation may result from not myocardial damage but skeletal muscle damage secondary to electrical cardioversion.

The present patient was shown to have isolated ACTH deficiency, and replacement therapy with hydrocortisone sufficiently improved her cardiomyopathy. Thus, we conclude that her myocardial dysfunction was closely related to adrenal insufficiency. Studies in adrenalectomized animals have suggested that cardiac function may be markedly impaired when stress is superimposed; increased catecholamine (cardioaccelerator) is toxic to a myocardium that is unprotected by glucocorticoids (23). Narayanan (24) showed that glucocorticoids are important for the maintenance of membrane calcium transport function in the cardiac sarcoplasmic reticulum from the rat, and may therefore affect myocardial contractility. He also demonstrated that microsomal phosphorylase activity in rat heart muscle is depleted by adrenalectomy. The decreased phosphorylase activity may impair glycogenolysis and thus induce the derangement of excitation-contraction coupling of the heart (25).

Cardiovascular complications have been associated with adrenal insufficiency (11-18, 26, 27). Four cases of reversible left ventricular dysfunction or cardiomyopathy associated with isolated ACTH deficiency have been reported (Table 2) (16-18). As far as we know, this is the first patient who complained of chest pain and in whom isolated ACTH deficiency associated with acute adrenal crisis caused Takotsubo cardiomyopathy. A case similar to the present one has been reported (18); a partial empty sella was noted in that case (18), but MRI was normal in the present case. Therefore, the morphologically normal pituitary may induce isolated ACTH deficiency complicated with Takotsubo cardiomyopathy. Futhermore, in the past case (18), it took more days to normalize the left ventricular contraction than in our case. It took a few days to make the diagnosis and start hydrocortisone therapy. In the present case, acute adrenal crisis was diagnosed promptly and treatment with supplemental hydrocortisone began very early in the clinical course. It is possible that early supplemental hydrocortisone lead myocardial injury to recover soon in Takotsubo cardiomyopathy. In the past cases (16), there were no symptoms suggestive of heart disease and left ventricular wall motion abnormalities present mainly around the left ventricular apex, returned to normal in 5 days. Deep negative $\mathrm{T}$ waves normalized 4 weeks after corticosteroid administration.

The cause of left ventricular dysfunction in Takotsubo cardiomyopathy is still unknown (1-8). It may represent a catecholamine-mediated myocardial stunning that results from a combination of myocardial ischemia related to diffuse microvascular dysfunction and, in some cases, multivessel epicardial spasm and metabolic injury (7). In view of the absence of any apparent coronary vasospasm during coronary angiography, we determined that coronary artery vasospasm might not occur in the present case. However, we could not comfirm the absence of coronary microvascular vasospasm.

It is possible that the cardiac injury observed in this patient was mediated by the sympathetic nervous system. Catecholamines can directly injure the myocardium $(28,29)$. In Takotsubo cardiomyopathy, physical stress is recognized 
as an important predisposing factor (7). She was critically ill and undoubtedly had intense activation of the sympathetic nervous system. Experimentally, brain-mediated cardiac injury can be prevented by total cardiac sympathectomy (30). Pharmacologic sympathetic blockade with propranolol and phentolamine also prevents myocardial necrosis after subarachnoid hemorrhage (31). Although the evidence is strong that catecholamines can cause an acute reversible cardiac injury, it is unclear why the apex of the heart is affected and the basal segments are spared. This may be partly explained by increased adrenergic receptor density in cardiac apical segments or increased apical myocardial responsiveness to adrenergic stimulation (32). Measurements of circulating catecholamine levels in patients presenting with the syndrome have shown inconsistent results (5). We suggest that in certain circumstances, adrenal crisis may cause Takotsubo cardiomyopathy.

\section{References}

1. Dote K, Sato H, Tateishi H, Uchida T, Ishihara M. Myocardial stunning due to simultaneous multivessel coronary spasms: a review of 5 cases. J Cardiol 21: 203-214, 1991 (in Japanese).

2. Kawai S, Suzuki H, Yamaguchi H, et al. Ampulla cardiomyopathy (Takotsubo cardiomyopathy)-reversible left ventricular dysfunction: with ST segment elevation. Jpn Circ J 64: 156-159, 2000 (Erratum in: Jpn Circ J 64:237, 2000).

3. Tsuchihashi K, Ueshima K, Uchida $T$, et al. Transient left ventricular apical ballooning without coronary artery stenosis: a novel heart syndrome mimicking acute myocardial infarction. Angina Pectoris-Myocardial Infarction Investigations in Japan. J Am Coll Cardiol 38: 11-18, 2001.

4. Akashi YJ, Nakazawa K, Sakakibara M, Miyake F, Koike H, Sasaka K. The clinical features of takotsubo cardiomyopathy. QJM 96: 563-573, 2003.

5. Kurisu S, Sato H, Kawagoe T, et al. Tako-tsubo-like left ventricular dysfunction: with ST-segment elevation: a novel cardiac syndrome mimicking acute myocardial infarction. Am Heart J 143: 448-455, 2002.

6. Abe Y, Kondo M, Matsuoka R, Araki M, Dohyama K, Tanio H. Assesment of clinical features in transient left ventricular apical ballooning. J Am Coll Cardiol 41: 737-742, 2003.

7. Bybee KA, Kara T, Prasad A, et al. Systemic review: transient left ventricular apical ballooning: a syndrome that mimics ST-segment elevation myocardial infarction. Ann Intern Med 141: 858-865, 2004.

8. Sharkey SW, Shear W, Hodges M, Herzog CA. Reversible myocardial contraction abnormalities in patients with an acute noncardiac illness. Chest 114: 98-105, 1998.

9. Williams GH, Dluhy RG. Hypofunction of the adrenal cortex. In: Harrison's Principles of Internal Medicine. 15-th ed. Braunwald E, Fauci AS, Kasper DL, et al, Eds. McGraw-Hill, New York, 2001: 2097-2100.

10. Ohnaka K, Haji M, Nawata H. Chronic adrenocortical insufficiency (primary, secondary). Ryoikibetsu-Shokogun Shirizu. 1993: 553-556 (in Japanese).

11. Walker C, Butt W. A case of cardiovascular collapse due to adrenal insufficiency. Aust Paediatr J 24: 197-198, 1988.

12. Boston BA, DeGroff C, Hanna CE, Reller M. Reversible cardiomyopathy in an infant with unrecognized congenital adrenal hyperpalasia. J Pediatr 124: 936-938, 1994.

13. Derish M, Eckert K, Chin C. Reversible cardiomyopathy in a child with Addison's disease. Intensive Care Med 22: 460-463, 1996.

14. Kubo S, Kitamura O, Orihara Y, Tsuda R, Hirose W, Nakasono I. Isolated adrenocorticotropic hormone deficiency: An autopsy case of adrenal crisis. A case report. Am J Forensic Med Pathol 18: 202-205, 1997.

15. Jialal I, Desai RK, Maharaj IC, Pala AS, Joubert SM. Isolated adrenocorticotrophic hormone (ACTH) deficiency associated with acute adrenal crisis. Post Med J 61: 423-425, 1985.

16. Iga K, Hori K, Gen H. Deep negative T waves associated with re- versible left ventricular dysfunction in acute adrenal crisis. Heart vessels 7: 107-111, 1992.

17. Eto K, Koga T, Sakamoto A, Kawazoe N, Sadoshima S, Onoyama K. Adult reversible cardiomyopathy with pituiary adrenal insufficiency caused by empty sella: a case report. Angiology 51: 319323, 2000.

18. Sakihara S, Kageyama K, Nigawara T, Kidani Y, Suda T. Ampulla (Takotsubo) cardiomyopathy caused by secondary adrenal insufficiency in ACTH isolated deficiency. Endocr J 54: 631-636, 2007.

19. Melmed S. Adrenocorticotropin hormone. In: Harrison's Principles of Internal Medicine. 15-th ed. Braunwald E, Fauci AS, Kasper DL, et al, Eds. McGraw-Hill, New York, 2001: 2047-2049.

20. Seth PS, Aurigemma GP, Krasnow JM, Tighe DA, Untereker WJ, Meyer TE. A syndrome of transient left ventricular apical wall motion abnormality in the absence of coronary disease: a perspective from the United States. Cardiology 100: 61-66, 2003.

21. Desmet WJ, Adriaenssens BF, Dens JA. Apical ballooning of the left ventricle: first series in white patients. Heart 89: 1027-1031, 2003.

22. Autman EM, Braunwald E. Acute myocardial Infarction. In: Laboratory Findings. Harrison's Principles of Internal Medicine. 15-th ed. Braunwald E, Fauci AS, Kasper DL, et al, Eds. McGraw-Hill, New York, 2001: 1387-1389.

23. Cleghorn RA. Cardiovascular failure in experimental adrenal insufficiency: a historical revival. Perspect Biol Med 27: 135-153, 1983.

24. Narayanan N. Effects of adrenalectomy and in vivo administration of dexamethasone on ATP-dependent calcium accumulation by sarcoplasmic reticulum from rat heart. J Mol Cell Cardiol 15: 7$15,1983$.

25. Narayanan N, Khandelwal RL. Microsomal phosphorylase in rat heart: Depletion following adrenalectomy and restoration by in vivo administration of dexamethasone. Endocrinology 117: 15441549, 1985.

26. Krug JJ. Cardiac arrest secondary to Adisson's disease. Ann Emerg Med 15: 735-737, 1986.

27. Nunoda S, Ueda K, Kameda S, Nakabayashi H. Sheehan's syndrome with hypomagnesemia and polymorphous ventricular tachycardia. Jpn Heart J 30: 251-256, 1989.

28. Mann D, Kent RL, Parsons B, Cooper G 4th. Adrenergic effects on the biology of the adult mammalian cardiocyte. Circulation $\mathbf{8 5}$ : 790-804, 1992.

29. White M, Wiechmann RJ, Roden RL, et al. Cardiac betaadrenergic neuroeffector systems in acute myocardial dysfunction related to brain injury. Evidence for catecholamine-mediated myocardial damage. Circulation 92: 2183-2189, 1995.

30. Novitzky D, Wicomb WN, Cooper DK, Rose AG, Reichart B. Prevention of myocardial injury during brain death by total cardiac sympathectomy in the Chacma baboon. Ann Thorac Surg 41: 520-524, 1986.

31. Neil-Dwyer G, Walter P, Cruickshank JM, Doshi B, O'Gorman P. Effect of propranolol and phentolamine on myocardial necrosis af- 
Inter Med 48: 347-352, 2009 DOI: 10.2169/internalmedicine.48.1662

ter subarachnoid haemorrhage. Br Med J 2: 990-992, 1978.

32. Mori H, Ishikawa $S$, Kojima $S$, et al. Increased responsiveness of left ventricular apical myocardium to adrenergic stimuli. Cardiovasc Res 27: 192-198, 1993.

(C) 2009 The Japanese Society of Internal Medicine

http://www.naika.or.jp/imindex.html 